\title{
HEALTHCARE SUPPLY CHAIN: HAS COVID MADE LEAN SIX SIGMA MORE EMPHATIC?
}

\author{
Ambika Bhatia \\ Department of Management \\ JIMS, New Delhi, Rohini Sector-5, Delhi, India \\ Sanjive Saxena \\ Department of Management \\ JIMS, New Delhi, Rohini Sector-5, Delhi, India \\ Prabhat Mittal, \\ Satyawati College, University of Delhi, \\ Delhi-110052
}

\begin{abstract}
The COVID pandemic has throttled the world by forcing mankind to accept the new abnormal and operate concomitantly with the realities of VUCA ecosystem. The Health Care Supply Chain Management System is enormously impacted. This paper addresses the issues and challenges in determining the emphaticalness of Lean Six Sigma in the health care supply chain domain. An extant review of literature has resulted in the formulation of the following research questions (a) what constitutes health care management system? (b) What components of Health Care supply chain management system are impacted by COVID and (c) How has the emphaticalness of Lean Six Sigma affected? In order to seek answers to these research questions, a structured approach was adopted. It commenced with the finalization of the topic followed by an extant review of literature. The literature review resulted in the formulation of research questions. The data was collected by means of Google forms and face to face interactions. The sampling technique deployed was purposive and the number of respondents targeted initially was 100 though after verification and validation they were reduced to 40 . The domain of the respondents included various hospitals, nursing homes from different job profiles. Grounded Theory was applied in the study. Descriptive and exploratory data analysis technique was applied. The study contributes to the existing literature in terms of new research of taking into account new domain of study. The managerial implications of the study that concerted approach is needed to make lean six sigma more profound. The research implication is the new domain and application of lean six sigma. A large sample size would have provided greater degree and depth of new findings. Future recommendation includes the customization of the findings to suit the work environment. The conclusion of the study results that health care management system is generics and it needs to be brought down to specifics to ensure that the reach of lean six sigma generates more emphaticalness.
\end{abstract}

Keywords-COVID, Emphatic, Health Care Management System, Lean Six sigma

\section{INTRODUCTION}

The world is mesmerized by the CORONA virus. For, this virus has ensured that the people are confined to stay indoors, ensure hygiene and to maintain social distancing norms. In other words, there is an innate eagerness to eliminate waste and to concentrate on what best can be achieved or obtained from what is available.

Supply chain management system in the case of hospitals is an important component. Hospitals, deal with crucial operations involving life and death of the admitted patients and supply chain management in hospital ensures that every attempt is made to work on the basics processes which aid the stakeholders in treating and managing patients as well as in the management of inventory items involving medicines and other necessary equipment's.

In times of COVID, with the focus on cost reduction and the elimination of waste, the importance of implementing lean six sigma has assumed a greater role.

This paper is an attempt to seek answer to the question Has COVID made lean six sigma more emphatic in terms of health care supply chain system in hospitals?

\section{LITERATURE REVIEW}

CORONA time has brought in great transformation in health care supply chain management systems. These changes have resulted in the form of emphasizing more focus on cost cutting measures and improvement in productivity. In the case of health care supply chain management system, this is more visible due to increase in CORONA cases and the urgent, immediate and specific resources to be delivered within timelines. In other words, the value provided by health care supply chain service providers must cater to provision of value, reduction in timelines while supplying the products 


\section{International Journal of Engineering Applied Sciences and Technology, 2020 \\ Vol. 5, Issue 6, ISSN No. 2455-2143, Pages 218-222 \\ Published Online October 2020 in IJEAST (http://www.ijeast.com)}

and above all provide value added services. All these translate to implementing and measuring the impact of lean six sigma operations Zipfel, et. al ,(2020).

Six Sigma as process improvement methodology was developed by Motorola. Earlier Six Sigma was conceived as a quality control process based methodology to control the defects in a manufacturing system. However, over a period of time it has involved in various forms and has made inroads to healthcare sectors too in the form of cost control, requirements management and controlling of waste in health care supply chain management services Folaron(2003), Kwak and Anbari, (2006). In the case of health care supply chain management systems, the processes associated with, are complex, complicated and are crucial to the functioning of the healthcare units as they directly or indirectly are related to the question of life support of the patient Beier (1995), Neumann, (2003), Jarrett, (2006).

With the passage of time the word lean came to be associated with Six Sigma. Several attempts were made by researchers to define the word lean from different perspectives. However, a common trend that became visible in the research work of several authors is enunciated as elimination of waste under the six sigma process improvement program Furterer et al. (2005), Heuvel et al. (2006); Gupta et al. (2013). Thus, lean six sigma came to associated with the process improvement that targets the elimination of wastage, cost reduction, delivery within timelines and any other associated components which will add value to the concerned stakeholder.

Today we are in the midst of CORONA times and the health care supply management system has assumed the lead role as infections from CORONA virus continue to remain untamed while being escalated to gigantic proportions. Hence, the moot question that has cropped up boils down to Has COVID made lean six sigma more emphatic? According to Dipu, (2020) the implementation of lean six sigma in services has a profound effect provided it is implemented in earnest in all the areas where it provides value addition to concerned stakeholders. In other words, the components of the lean six sigma must be identified, the data representing their base conditions be made available, studied thoroughly and then steps taken to develop processes and implement them in rigour and practice, driven by top management. He further corroborates that these are put to test during the crucial time in which are presently ensconced.

\section{RESEARCH QUESTIONS}

An extant review of literature resulted in the generation of the following research question

(a) What constitutes health care management system? (b) What components of Health Care supply chain management system are impacted by COVID?

(c) How has the emphaticalness of Lean Six Sigma affected?

\section{RESEARCH METHODOLOGY}

Structured research methodology was adopted for the development of the research paper. It commenced with the process of development of the topic in the context of healthcare supply chain, the COVID scenario, the application of Six Sigma and the forcefulness of the lean six sigma process as a whole within the domain of healthcare supply chain system. After several round of discussions and deliberations the topic agreed upon by the authors.

The next stage rotated on the process of literature review. The literature review was a concomitant process and several iterations were performed to as to give definite and concrete shape to the paper. The development of the research questions were a fallout of the review of literature.

The research design was the next stage of the study. The research design was based on the grounded theory approach. The reason for deploying grounded theory approach is attributed to the fact the grounded theory approach provides the real life environmental situations to understand the research problem in a more realistic manner.

The design of the questionnaire was the next stage of the process. The questionnaire was divided into 2 parts. One part captured the demographic details of the respondents while the other part captured the responses of the respondents. The questions in the questionnaire were multiple choice answer types.

The sample technique adopted in the process was purposive. The choice of implementing purposive sampling was based on the research topic, the COVID situation and other factors which acted either as constraints or as supporting factors. The Data was extracted and analysed by means of MS Excel 2016 software. Exploratory and descriptive data analysis technique was applied. The reason for applying exploratory and descriptive data analysis was the fact that six sigma operates in an iterative manner. It starts with the process of taking data of existing ground reality, developing processes, implementing them and making modifications to the processes so as to generate improvised data. It is this data which classifies the success or failure of six sigma program. On the other hand, six sigma program functions in an integrated manner meaning that it works on the relationship amongst the various variables or components and exploratory data analysis deals with the relationships amongst the variables.

The findings and interpretations are developed in the context of the research questions. The contribution to the study, limitations of the study, the future recommendations and the research implications are documented in the context of the 


\section{International Journal of Engineering Applied Sciences and Technology, 2020 \\ Vol. 5, Issue 6, ISSN No. 2455-2143, Pages 218-222 \\ Published Online October 2020 in IJEAST (http://www.ijeast.com)}

research study. The managerial implications are written with the purpose of the applicability of the findings from the healthcare supply chain perspectives. The conclusions are documented in response to the research questions.

\section{FINDINGS}

Demographic Distribution

a. Hospital type

Table 1: Distribution of Type of Hospital

\begin{tabular}{|c|c|c|}
\hline Hospital type & Count & Percentage \\
\hline Government & $\mathbf{6}$ & 15 \\
\hline Private & 23 & 57.5 \\
\hline Others & 11 & 27.5 \\
\hline
\end{tabular}

Table 1, depicts the demographic distribution of the types of the hospital covered in the research study. Government hospitals represent $15 \%$ of the sample respondents while the private hospitals constitute $57.5 \%$ of the sample respondents. On the other hand, other types of hospitals constitute $27.5 \%$ of the sample respondents. The findings, depicted in the above table indicate that the sampling technique was purposive on account of the fact that the representation of the government hospital is very low as compared to the other two types of hospitals under study. The reason for inclusion of limited number of government hospitals is attributed to the fact that government hospitals are governed by government procedures and adopting practices which require implementation of six sigma is long and arduous process as it requires many approvals and sanctions from various authorities. Hence the low representation. On the other hand, private and other types of hospitals are free to adopt any practices which will improve the process and hence decrease the operational cost. Hence the higher percentage or representation of hospitals.

\section{b. Managerial experience}

Table 2: Distribution of Experience levels of various stakeholders connected to various operations in Hospital

\begin{tabular}{|c|c|c|}
\hline Experience & Count & Percentage \\
\hline $\begin{array}{c}\text { Less than or equal to 5 } \\
\text { years }\end{array}$ & 1 & 2.5 \\
\hline Between 6 to 10 years & 8 & 20 \\
\hline Between 11 to 15 years & 4 & 10 \\
\hline More than 15 years & 27 & 67.5 \\
\hline
\end{tabular}

Table 2 depicts the distribution of the experience level of various key stakeholders which are directly or indirectly connected with the various operations performed in hospital. It is seen that the highest percentage of the sample respondents comprise of stakeholders having more than 15 years of experience. As the sampling technique is purposive and the initiatives such as six sigma require the support of senior stakeholders hence their inclusion comprise of the majority of the sample respondents.
Constituents of Health care management system

a. IT Integration with the Suppliers

Table 3: Distribution components of Health Care Supply Chain Management System for IT integration

\begin{tabular}{|c|c|c|}
\hline Sub-component & Count & Percentage \\
\hline $\begin{array}{c}\text { Availability of IT infrastructure for } \\
\text { managing information across the } \\
\text { key suppliers }\end{array}$ & 6 & 15 \\
\hline E-invoices, purchase orders & 14 & 35 \\
\hline $\begin{array}{c}\text { Online Tracking of orders and } \\
\text { shipments }\end{array}$ & 11 & 27.5 \\
\hline $\begin{array}{c}\text { Inter-organizational linkages with } \\
\text { INTRANET system }\end{array}$ & 5 & 12.5 \\
\hline $\begin{array}{c}\text { Electronic mailing capabilities with } \\
\text { key suppliers }\end{array}$ & 2 & 5 \\
\hline $\begin{array}{c}\text { ERP Software for integration with } \\
\text { the key vendors/suppliers }\end{array}$ & 2 & 5 \\
\hline
\end{tabular}

Table 3, depicts the distribution of the constituents of health care supply chain management system. The highest rating of 35 is given to the sub component which comprise of the purchasing process. This is crucial aspect in the implementation of lean six sigma program. As the input to the six sigma program commences with purchasing process and the strict implementation of management controls at the purchasing process goes a long way in ensuring that defect age, a crucial component in reducing the number of defects is managed and controlled. The next in order of the crucial component of lean six sigma implementation if the injection of technology and in managing the operational processes by means of Intranet and the availability of IT infrastructure. This is attributed to the tune of $12.5 \%$. The next major component is tracking mechanism, a very crucial component for determining the emphaticalness of lean six sigma implementation.

\section{b. Environment Uncertainty with the Suppliers}

Table 4: Distribution components of Health Care Supply Chain Management System for Environment Uncertainty

\begin{tabular}{|c|c|c|}
\hline Sub-component & Count & Percentage \\
\hline $\begin{array}{c}\text { Patient's clinical preferences } \\
\text { change often with time }\end{array}$ & 10 & 25 \\
\hline $\begin{array}{c}\text { There is a need of new and } \\
\text { updated products are required } \\
\text { frequently }\end{array}$ & 9 & 22.5 \\
\hline $\begin{array}{c}\text { New diseases and treatments } \\
\text { upcoming frequently }\end{array}$ & 8 & 20 \\
\hline $\begin{array}{c}\text { Excessive competition in } \\
\text { healthcare industry }\end{array}$ & 9 & 22.5 \\
\hline $\begin{array}{c}\text { Trend of Usage of social media and } \\
\text { internet for self-medications has } \\
\text { increased }\end{array}$ & 29 & 72.5 \\
\hline
\end{tabular}




\section{International Journal of Engineering Applied Sciences and Technology, 2020 \\ Vol. 5, Issue 6, ISSN No. 2455-2143, Pages 218-222 \\ Published Online October 2020 in IJEAST (http://www.ijeast.com)}

Table 4, depicts the distribution of the environmental uncertainty in the determining the emphaticalness of lean six sigma program in the context of suppliers. It is observed that the highest value of 72.5 constitutes the crucial environmental factor which impacts the lean six sigma program. It is well known that social media plays a great role in influencing the masses and this needs to be tackled and accounted for if Six Sigma is needed to be implemented in earnest. Further, as previous research, six sigma champions draft strategy to control this crucial factor. Further, in times of CORONA, these environmental factors were controlled by various government agencies so as to minimize the impact of corona in lean six sigma implementation.

\section{c. Lean Six Sigma Implementation}

Table 5: Distribution components of Health Care Supply Chain Management System for Environment Uncertainty

\begin{tabular}{|c|c|c|}
\hline Sub-component & Count & Percentage \\
\hline $\begin{array}{c}\text { Hospital's Key strategy is to reduce } \\
\text { waste }\end{array}$ & $\mathbf{8}$ & 20 \\
\hline $\begin{array}{c}\text { Quick and smooth flow of the stock } \\
\text { and materials from inventory to } \\
\text { doctors and Physicians }\end{array}$ & 4 & 10 \\
\hline $\begin{array}{c}\text { Willingness to reengineer the } \\
\text { processes to eliminate waste }\end{array}$ & 4 & 10 \\
\hline $\begin{array}{c}\text { Implementation of preventive and } \\
\text { predictive maintenance procedures. }\end{array}$ & 6 & 15 \\
\hline $\begin{array}{c}\text { Removals of the barriers in waste } \\
\text { reduction processes. }\end{array}$ & 12 & 30 \\
\hline $\begin{array}{c}\text { Improvement in the Quality of } \\
\text { order fulfillment process. }\end{array}$ & 6 & 15 \\
\hline
\end{tabular}

Table 5 depicts the distribution of lean six sigma implementation program. The highest value of $30 \%$ is attributed to the removal of barriers for waste reduction processes. Despite being low number of respondents of having answered affirmatively yet these are encouraging signs indicating that lean sigma implementation is more emphatic as people have realised the importance of reducing waste in many of operational aspects. The next crucial component is attributed to the strategy adopted by hospital staff in reducing the waste. This indicates that management support is essential in these initiatives in order to make it a success.

\section{CONTRIBUtion to EXISTING STUDY}

The study in its present form has tried to link the components of lean six sigma, health care and health care supply chain management systems. As far as the existing literature is concerned studies have been conducted on individual components only in terms of health care services in a specific domain of health care supply chain management systems. By linking these three different components the study as generated a new avenue for research on macro level.

\section{MANAGERIAL IMPLICATIONS}

The managerial implications of the study lies in the fact the methodology and the findings can be tailored to meet the organizational demand of implementing lean six sigma operations in the health care supply chain system. In other words, execution plans can be drawn to meet the objectives of lean six sigma processes and goals of healthcare supply chain management systems.

\section{RESEARCH IMPLICATIONS}

The research implication of the study is the fact that health care supply chain system is a dynamic system. It keeps on changing which means new variables are to be identified and their interactions with the lean six sigma process could provide impetus to research implications.

\section{FUTURE RECOMMENDATIONS}

The future recommendation of the study results in the findings which can be customized to suit the needs and applications of lean six sigma program to a healthcare supply chain system dealing in specific type of healthcare services. For example, the findings of the study can be tailored to apply lean six sigma in health care supply chain system of health care centres catering to disabled persons.

On the other hand, as health care is a dynamic industry and so is the supply chain the findings of the study can be suitable amended to meet the changing market dynamics of health care industry.

\section{LimitATIONS}

The limitations that surfaced during the course of the research study is the impact of CORONA pandemic which resulted in limited mobility on account of restrictions in meeting the respondents from the hospital, nursing homes and other medical centres. This resulted in collection of partial or inadequate information from face to face interactions. Also the small sample size and the majority of the data collection by Google forms resulted in the findings which otherwise would have greater ramifications to other types of healthcare centres.

\section{CONCLUSION}

The study has demonstrated the need for studying the emphaticalness of six sigma program in the COVID times in the supply chain management process. In order to study and to ensure that lean six sigma program, the prime need is to determine the various components which constitute the health care management system and how these components are needed to be integrated with the various aspects of six sigma. Further, the study has highlighted that COVID times has induced a sense of discipline in the hospital supply chain mechanism process and that the program has emphatically 
Published Online October 2020 in IJEAST (http://www.ijeast.com)

demonstrated that the program can produce results in normal times also.

\section{REFERENCE}

[1] Beier, F. J.(1995). The management of the supply chain for hospital pharmacies: a focus on inventory management practices, Journal of Business Logistics, vol. 16, no. 2, (pp. 153-174)

[2] Dipu, KV, (2020), Relevance of Lean Six Sigma in the times of COVID-19, Express computer, May, 26, https://www.expresscomputer.in/indiaincfightscovid19/rel evance-of-lean-six-sigma-in-the-times-of-covid-

$19 / 56683 /$

[3] Folaron, J. (2003). The evolution of Six Sigma, Six Sigma Forum Magazine, vol. 2, no. 4, (pp. 38-44)

[4] Furterer, S. and Elshennawy, A.K. (2005), Implementation of TQM and Lean Six Sigma tools in local government: a framework and a case study, Total Quality Management \& Business Excellence, Vol. 16 No. 10, (pp. 1179-1191)

[5] Gupta, V., Acharya, P. and Patwardhan, M. (2013), A strategic and operational approach to assess the lean performance in radial tyre manufacturing in India: a case based study,International Journal of Productivity and Performance Management, Vol. 62 No. 6, (pp. 634-651)

[6] Jarrett , P. G. (2006). An analysis of international health care logistics: the benefits and implications of implementing just-in-time systems in the health care industry, Leadership in Health Services, vol. 19, no. 1, (pp. 1-10)

[7] Koning, H., Verver, J.P., Heuvel, J., Bisgaard, S. and Does, R.J. (2006), Lean Six Sigma in healthcare, Journal for Healthcare Quality, Vol. 28 No. 2, (pp. 4-11)

[8] Kwak, Y. H. and F. T. Anbari. (2006), Benefits,

[9] Neumann ,L. (2003). Streamlining the supply chain," Healthcare Financial Management, vol. 57, no. 7, (pp. 56-62, 2003)

[10] Zipfel, N., Groenewoud, A. S., Rensing, B. J. W. M., Daeter, E. J., Dijksman, L. M., Dambrink, J.-H. E., Vander Nat, P. B. (2020). Selecting interventions to improve patient-relevant outcomes in health care for aortic valve disease - the Intervention Selection Toolbox.
BMC Health Services Research, 20(1). doi:10.1186/s12913-020-05090-Z 